\title{
Title: Identification and Characterization of a Human DNA Double-Strand Break Repair Complex
}

Los Alamos National Laboratory, an affirmative actionequal opportunity empioyer, is operated by the University of California for the U.S. Department of Energy uncer contract W-7405-ENG-36. By accedtance of this article, the publisher recognizes that the U.S. Government retains a nonexciusive, royaityfree license to puolish or reproduce the published tom of this contribution, or to ailow others to do so. $i$ : U.S. Government purposes. Los Alamos National Laboratory requests that the publisher identify this arcle as work periormed under the auspices of the U.S. Department of Energy. Los Alamos National Laboratory strongty supports academic freedom and a researcher's right to publish; as an institution, however, the Laboratory does not endorse the viewpoint of a pubtication or guarantee its technicai correctness. 


\section{DISCLAIMER}

This report was prepared as an account of work sponsored by an agency of the United States Government. Neither the United States Government nor any agency thereof, nor any of their employees, make any warranty, express or implied, or assumes any legal liability or responsibility for the accuracy, completeness, or usefulness of any information, apparatus, product, or process disclosed, or represents that its use would not infringe privately owned rights. Reference herein to any specific commercial product, process, or service by trade name, trademark, manufacturer, or otherwise does not necessarily constitute or imply its endorsement, recommendation, or favoring by the United States Government or any agency thereof. The views and opinions of authors expressed herein do not necessarily state or reflect those of the United States Government or any agency thereof. 


\section{DISCLAIMER}

Portions of this document may be illegible in electronic image products. Images are produced from the best available original document. 


\title{
Identification and Characterization of a Human DNA Double-Strand Break Repair Complex
}

David J. Chen* and Robert B. Cary (LS-6)

\begin{abstract}
We have used atomic force microscopy (AFM) to characterize the assembly and structure of the macromolecular assemblies involved in DNA repair. We have demonstrated using AFM that the DNA-dependent protein kinase can play a structural role in the repair of DNA double-strand breaks (DSBs) by physically holding DNA ends together. We have extended these studies to include other DNA damage response proteins. these efforts have resulted in important and novel findings regarding the ATM protein. Specifically, our work has demonstrated. for the first time, that the ATM protein binds with specificity to a DNA end. This finding is the first to implicate the ATM protein in the detection of DNA damage by direct physical interaction with DSBs.
\end{abstract}

\section{Background and Research Objectives}

The continued study of cellular response to DNA damage has revealed many proteins involved in the response/repair of DNA damage, but the assignment of specific functions to many of these proteins has proven elusive. The AFM is uniquely suited to investigate these type of biological questions and provides a means by which macromolecular interactions can be visualized under native conditions. By employing AFM we are able to visualize the interactions of several of the DNA repair proteins with DNA and other proteins. Our studies intend to provide a better understanding of the structure, function and dynamics of protein-DNA complexes formed by DNA damage response proteins.

*Principal Investigator, e-mail: dchen@lanl.gov 
Importance to LANL's Science and Technology Base and National R\&D Needs

In the study of DNA repair proteins AFM is useful for the analysis of DNA-protein interactions, DNA conformational changes, and structural studies of large proteins or muitiprotein assemblies. AFM represents state-of-the-art technology and has been utilized to obtain structural and functional information about the DNA-PK enzyme. (Cary, et al. 1997; Chiu. et al 1998). The capabilities of AFM are not limited to the study of DNA repair proteins, or biological systems. but can rapidly be applied to any number of systems requiring microscopic examination. The simplicity of sample preparation, sub molecular resolution, and rapidity of data collection makes the atomic force microscope a powerful and versatile instrument with applications in many biological and non-biological systems.

\section{Scientific Approach and Accomplishments}

The atomic force microscope is a high resolution technique with several advantages over more traditional microscopic approaches. With the ability to image unstained and uncoated protein-nuclesc acid complexes in air. aqueous buffers or organic solvents, the AFM is uniquely suited for biological studies and provides a means by which macromolecular interactions can be visualized under native conditions. The application of AFM to current questions in DNA repair biology has proven a powerful means to investigate the function of DNA repair proteins. We have demonstrated with AFM that the DNA-dependent protein kinase can play a structural role in the repair of DNA double-strand breaks (DSBs) by physically holding DNA ends together. Presumably, this behavior aids in the correct covalent repair of the DSB by tethering the broken ends until covalent repair can be accomplished (Cary, et al. 1997; Figure 1). These studies suggest that this protein may be responsible for assuring correct rejoining of the broken chromosomes that result from exposure to ionizing radiation. Thus, our studies have revealed important clues to the functional role of DNA-PK in mammalian DNA repair. The studies of DNA repair protein interaction with DNA have been expanded to include other DNA damage response proteins and more complex DNA based substrates. These studies have resulted in important and novel findings regarding the ATM protein, the protein defective in patients suffering from the disease known as ataxia-telangiectasia, a condition characterized in part by increased sensitivity to ionizing radiation and a predisposition to cancer. This work has demonstrated, for the first time, that the ATM protein binds directly to DNA. Moreover, our ability to directly visualize the protein in association with DNA using AFM has allowed us to conclude that the ATM protein binds with specificity to the DNA end. This finding is the first to implicate the ATM protein in the detection of DNA damage by direct physical interaction with DSBs. These studies have revealed important properties of the DNA-PK 
and ATM proteins and demonstrate that the AFM will provide an indispensable tool for the characterization of the macromolecular complexes invoived in DNA repair.

\section{Publications}

1. Cary, R. B., Peterson. S. R.. Wang, J., Bear. D. G., Bradbury, E. M. \& Chen. D. J. (1997)"DNA looping by Ku and the DNA-dependent protein kinase" Proc. Natl. Acad. Sci. USA. 94(\#9), pp 4267-4272. 1997

\section{References}

[1] Chiu. C.Y.. Cury. R.B., Chen. D.J., Peterson. S.R., Stewart, P.L.. "Cryo-EM Imaging of the Catylitic Subunit of the DNA-Dependent Protein Kinase" Journal of Molecular Biology , v. 284(\#4), pp 1075-1081, 1998 


\section{Figure}

Figure 1. DNA-PK assembles on the ends of DNA. AFM studies demonstrate that the end-bound DNA-PK complexes (white arrows) can self-associate to hold the ends of DNA molecules together (black arrows). 


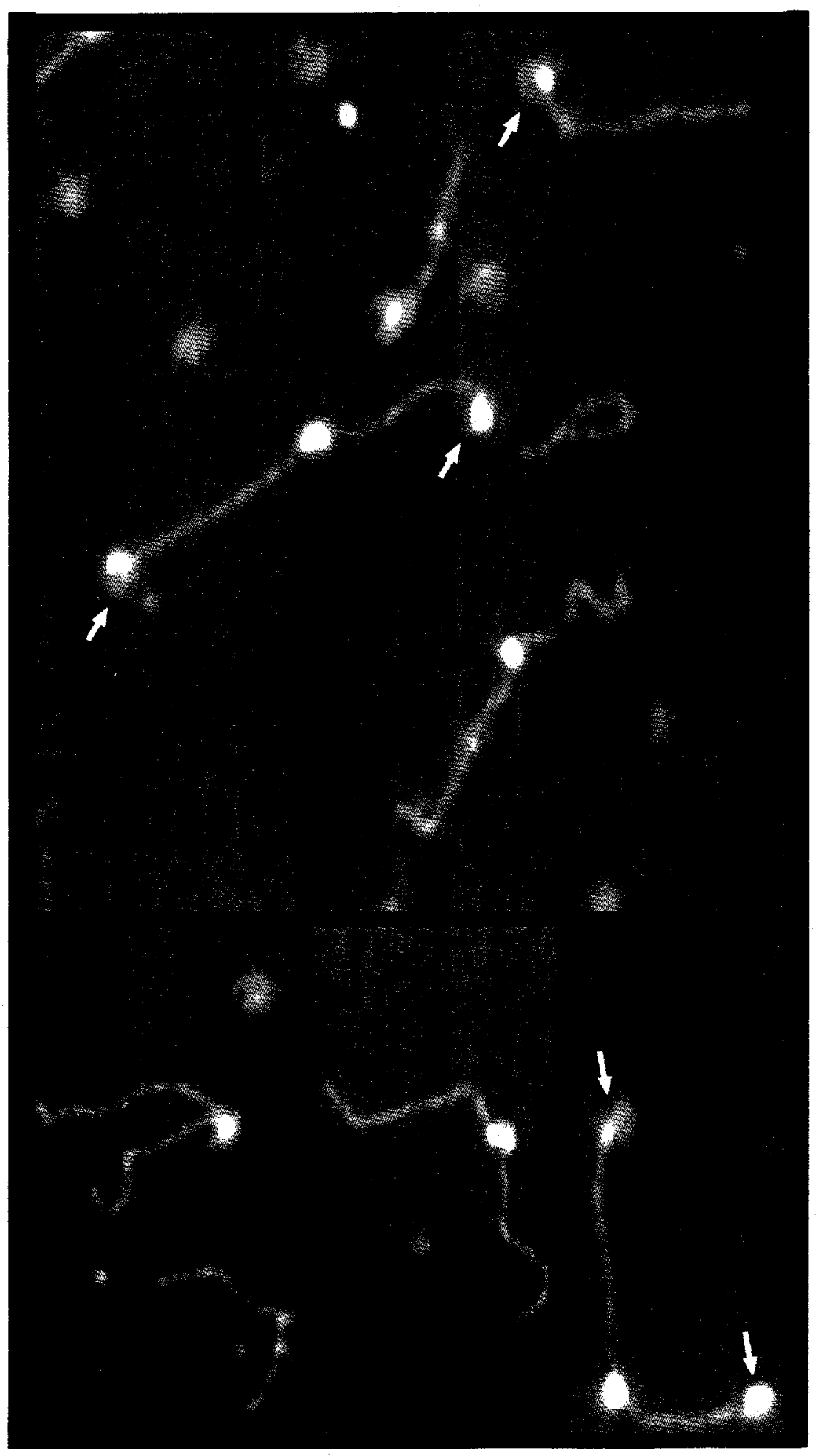

